\title{
A Simple Way to Prepare Nanosize NiO Powder by Mixing Acidic Ni Compound with Basic Ni Compound
}

\author{
Deock-Soo Cheong*, Dong Hun Yun**, Sang Hwan Park**, and Chang-Sam Kim**** \\ *Department of MATSE, Dankook University, Cheonan 330-714, Korea \\ **Division of MATSE, Korea Institute of Science and Technology, Seoul 136-791, Korea \\ ***Battery Research Center, Korea Institute of Science and Technology, Seoul 136-791, Korea
}

(Received October 5, 2009; Accepted October 26, 2009)

\begin{abstract}
Nanosize NiO powder was prepared by mixing acidic nickel nitrate with basic nickel carbonate. The particle size and morphology of $\mathrm{NiO}$ were mainly governed by the mole ratio of the nitrate to the carbonate. The effects were studied by DSC, XRD, FTIR, and SEM. Heat treatment conditions influence the particle size distribution of produced $\mathrm{NiO}$ powder extensively for the case of $3 \mathrm{~N} 7 \mathrm{C}$ (3 moles of the nitrate and 7 moles of the carbonate) and $4 \mathrm{~N} 6 \mathrm{C}$, but only slightly for $1 \mathrm{~N} 9 \mathrm{C}$ and $2 \mathrm{~N} 8 \mathrm{C}$. Uniform pseudospherical $\mathrm{NiO}$ particles were obtained in $50 \sim 70 \mathrm{~nm}$ for $1 \mathrm{~N} 9 \mathrm{C}$ and $30 \sim 60 \mathrm{~nm}$ for $2 \mathrm{~N} 8 \mathrm{C}$ by calcination at $750^{\circ} \mathrm{C}$ for $2 \mathrm{~h}$.
\end{abstract}

Key words : Nanosize NiO, Nickel nitrate, Basic nickel carbonate, Calcination effects, DSC

\section{Introduction}

$\mathrm{N}$ $\mathrm{iO}$ is an important inorganic material. It is extensively used in catalysis, electrochromic films, magnetic materials, gas sensors, cathodes of alkaline batteries, and anodes of solid oxide fuel cells (SOFC) ${ }^{1-6)}$ There are many chemical methods reported for the synthesis of $\mathrm{NiO}$ particles, including the precipitation of acidic nickel salt such as $\mathrm{NiCl}_{2}$, $\mathrm{Ni}\left(\mathrm{NO}_{3}\right)_{2}$ or $\mathrm{NiSO}_{4}$ with base such as $\mathrm{NaOH}, \mathrm{NH}_{4} \mathrm{HCO}_{3}$, $\mathrm{CO}\left(\mathrm{NH}_{2}\right)_{2}$, or ammonia, ${ }^{7-9)}$ forming nickel complex with ligands, such as oxalic acid, citric acid, malic acid, etc., ${ }^{10-17)}$ using molten salt, ${ }^{18,19)}$ etc. All these methods are accomplished by the introduction of other chemicals, so the byproducts have to be removed by filtration and washing.

If a basic metal compound can be used as a base instead of a common base, such as an ammonia solution or $\mathrm{NaOH}$, then there will be no need to remove formed salts, which makes the process simple and economic.

In this paper we would like to introduce a simple way to prepare $\mathrm{NiO}$ powder by inducing reactions between acidic Ni precursor and basic Ni precursor by mixing, followed by calcination. We found it interesting that the ratio of the acid to the base governs the particle size and morphology of the produced $\mathrm{NiO}$ powder.

\section{Experimental Procedure}

$\mathrm{Ni}\left(\mathrm{NO}_{3}\right)_{2} \cdot 6 \mathrm{H}_{2} \mathrm{O}$ (purity $98.0 \%$ Aldrich Chem., U.S.A.) and

${ }^{\dagger}$ Corresponding author: Chang-Sam Kim

E-mail : cskim@kist.re.kr

Tel : 82-2-958-5483 Fax : +82-2-958-5548
$2 \mathrm{NiCO}_{3} \cdot 3 \mathrm{Ni}(\mathrm{OH})_{2}$ (purity $99.0 \%$ Aldrich Chem., U.S.A.) were used as received. The two nickel compounds were mixed at a mole ratio of the acid to the base of $1: 9$ (1N9C), 2:8 (2N8C), 3:7 (3N7C) and 4:6 (4N6C). The mixtures were prepared as aqueous slurries by ball milling for $8 \mathrm{~h}$. The slurries were dried using a rotary evaporator and then subjected to calcination. Heat treatment conditions were varied and the effects were studied. The dried mixtures ( 30 mg) were heated to $700^{\circ} \mathrm{C}$ in an alumina crucible at a heating rate of $10^{\circ} \mathrm{C} / \mathrm{min}$ under flowing air using TG/DSC (Model STA 409C, Netzsch Co., Germany). The DSC of the 2N8C showed an endothermic peak at $308^{\circ} \mathrm{C}$. The mixture was heated to its set-on and set-off temperatures and cooled rapidly to room temperature. The powders were subjected to XRD (Model DMAX llA, Rigaku Co., Japan) and FTIR (Model 100 with ATR, Perkin-Elmer Inc., U.S.A) analysis. The powder morphology was observed by SEM (Model 3000M, Hitachi Co., Japan).

\section{Results and Discussion}

The strategy to prepare uniform $\mathrm{NiO}$ powder is derived from the following; i) $\mathrm{NiO}$ powder can be obtained by the calcination of almost any nickel compound in air ${ }^{20,21)}$ ii) $\mathrm{NiO}$ powder obtained from the calcination of $\mathrm{NiCO}_{3} \cdot 2 \mathrm{Ni}(\mathrm{OH})_{2}$ at $650^{\circ} \mathrm{C}$ for $2 \mathrm{~h}$ shows $50 \sim 100 \mathrm{~nm}$ cube crystals and that from $\mathrm{Ni}\left(\mathrm{NO}_{3}\right)_{2} \cdot 6 \mathrm{H}_{2} \mathrm{O}$ consists of two kinds of cubic particles ranging from about $100 \mathrm{~nm}$ to $800 \mathrm{~nm}$ in size, which indicates that there are two kinds of growing modes, ${ }^{22)}$ and iii) acidic nickel nitrate can react with basic nickel carbonate via the Lewis acid-base interaction. If the proper amount of the nickel nitrate is introduced to the nickel carbonate to control the growing mode of in-situ formed $\mathrm{NiO}$ particles, uni- 


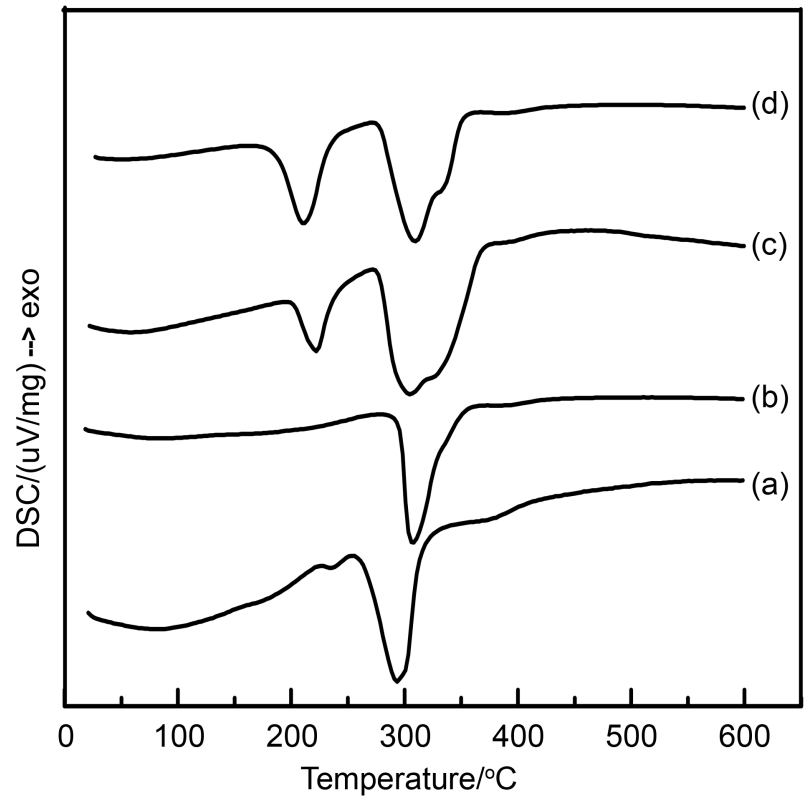

Fig. 1. DSC curves of $\mathrm{NiO}$ precursors of: (a) $1 \mathrm{~N} 9 \mathrm{C}$, (b) $2 \mathrm{~N} 8 \mathrm{C}$, (c) $3 \mathrm{~N} 7 \mathrm{C}$, and (d) $4 \mathrm{~N} 6 \mathrm{C}$ heated in an alumina crucible at a heating rate of $10^{\circ} \mathrm{C} / \mathrm{min}$ under flowing air.

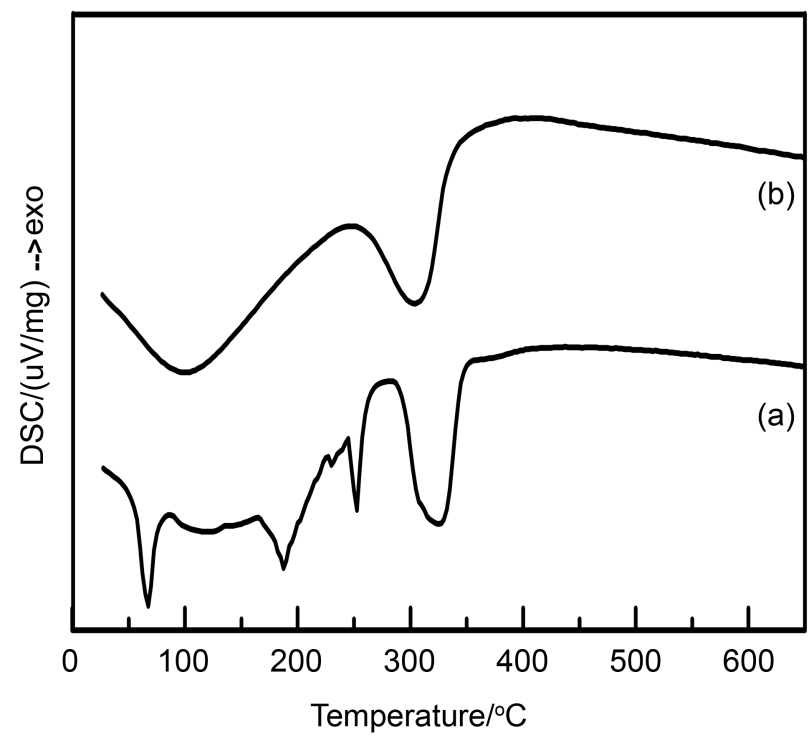

Fig. 2. $\mathrm{DSC}$ curves of: (a) $\mathrm{Ni}\left(\mathrm{NO}_{3}\right)_{2} 6 \mathrm{H}_{2} \mathrm{O}$ and (b) $2 \mathrm{NiCO}_{3}$ $\cdot 3 \mathrm{Ni}(\mathrm{OH})_{2}$ heated in an alumina crucible at a heating rate of $10^{\circ} \mathrm{C} / \mathrm{min}$ under flowing air.

form spherical nanosize $\mathrm{NiO}$ powder may be obtained.

Thus, the nickel compounds were mixed at various mole ratios and their DSC curves are shown in Fig. 1. Comparing their curves with those of the carbonate and the nitrate shown in Fig. 2, considerable differences were observed. The nickel carbonate shows two endothermic peaks at $\sim 100$ and $305^{\circ} \mathrm{C}$ and the nitrates four endothermic peaks at 68,187 , 253 , and $325^{\circ} \mathrm{C}$. However, the mixtures show new peaks. $1 \mathrm{~N} 9 \mathrm{C}$ and $2 \mathrm{~N} 8 \mathrm{C}$ show a single new strong endodermic peak at $302^{\circ} \mathrm{C}$ and $308^{\circ} \mathrm{C}$, respectively, but $3 \mathrm{~N} 7 \mathrm{C}$ shows two endothermic peaks around 222 and $305^{\circ} \mathrm{C}$ and $4 \mathrm{~N} 6 \mathrm{C}$ at 211

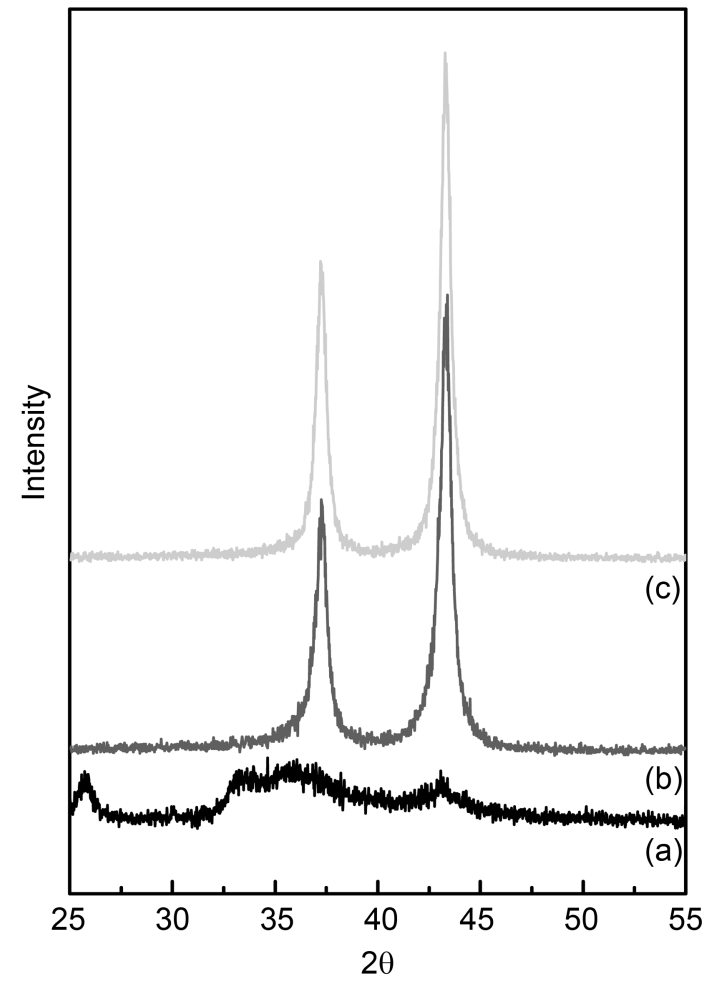

Fig. 3. XRD patterns of the $2 \mathrm{~N} 8 \mathrm{C}$ precursor heated to various temperatures of its DSC curve and then cooled rapidly to ambient temperature: (a) $280^{\circ} \mathrm{C}$, (b) $370^{\circ} \mathrm{C}$, and (c) $430^{\circ} \mathrm{C}$.

and $310^{\circ} \mathrm{C}$. Both of them show a shoulder peak around $326^{\circ} \mathrm{C}$, which indicates that some of the nitrate remained. The single peak for $1 \mathrm{~N} 9 \mathrm{C}$ and $2 \mathrm{~N} 8 \mathrm{C}$ indicates that almost no nitrate or the carbonate remains. The $2 \mathrm{~N} 8 \mathrm{C}$ mixture was heated to the set-on and set-off temperatures of its DSC curve without holding at a heating rate of $10^{\circ} \mathrm{C} / \mathrm{min}$ and were cooled rapidly, and their XRD patterns are shown in Fig. 3. $\mathrm{NiO}$ was not formed by $280^{\circ} \mathrm{C}$ but by $370^{\circ} \mathrm{C}$, and further heating to $430^{\circ} \mathrm{C}$ increased the intensity slightly, which is assigned as a cubic phase (JCPDS card file 73-1523). However, their FT-IR shown in Fig. 4 indicates that there is $\mathrm{NiO}(\mathrm{OH})$ due to the presence of peaks around 3500 and $1630 \mathrm{~cm}^{-1}$ assigned to $\mathrm{O}-\mathrm{H}$ stretching and bending, respectively. Therefore the endothermic peaks around $310^{\circ} \mathrm{C}$ are attributed to the formation of crystalline $\mathrm{NiO}$ and amorphous $\mathrm{NiO}(\mathrm{OH})$, and this is also supported by the dark grey color.

The mixtures were heated to $750^{\circ} \mathrm{C}$ at a heating rate of $5^{\circ} \mathrm{C} / \mathrm{min}$ and then held at that temperature for $2 \mathrm{~h}$. Their SEM pictures shown in Fig. 5 indicate that calcined 1N9C and $2 \mathrm{~N} 8 \mathrm{C}$ show homogeneous pseudo spherical particles with an average particle size of $\sim 50 \mathrm{~nm}$ and $\sim 70 \mathrm{~nm}$, respectively, but $3 \mathrm{~N} 7 \mathrm{C}$ and $4 \mathrm{~N} 6 \mathrm{C}$ consists of two kinds of particles: small spherical particles and large cubic crystals, which was attributed to the free nickel nitrate that was not fully dissipated the heat due to the rapid heating rate. Thus, the mixtures were heated to $200^{\circ} \mathrm{C}$ at a heating rate 


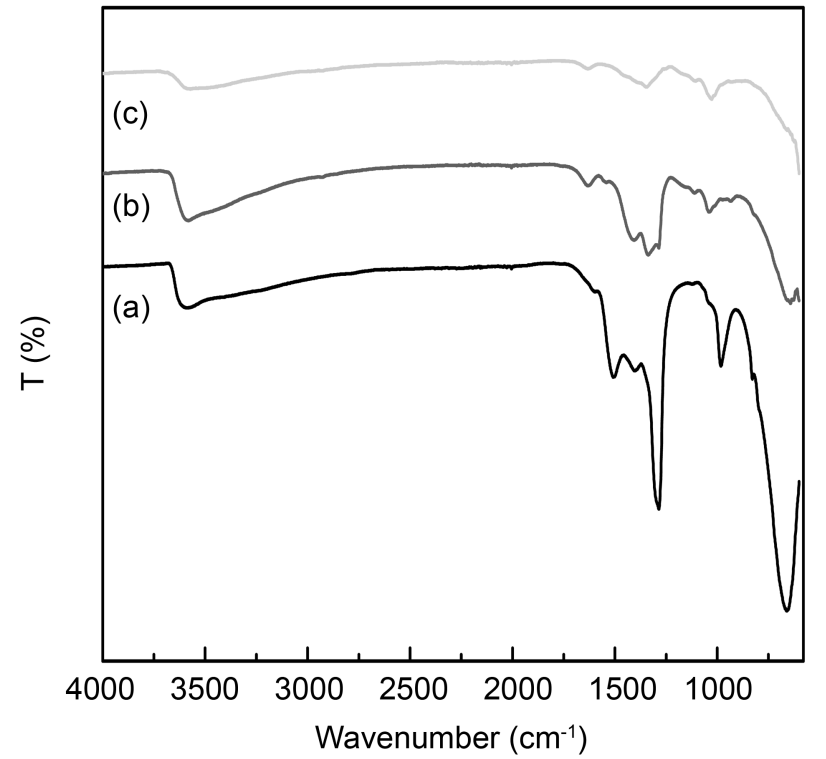

Fig. 4. FTIR spectra of the $2 \mathrm{~N} 8 \mathrm{C}$ samples heated to various temperatures as in Fig. 3 (a) $280^{\circ} \mathrm{C}$, (b) $370^{\circ} \mathrm{C}$, and (c) $430^{\circ} \mathrm{C}$.

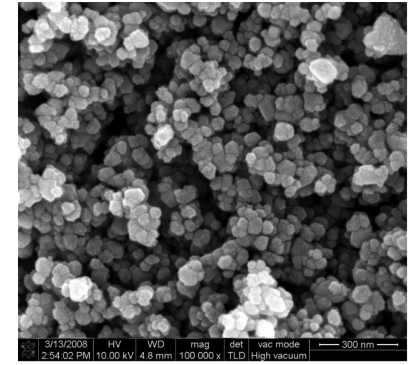

(a)

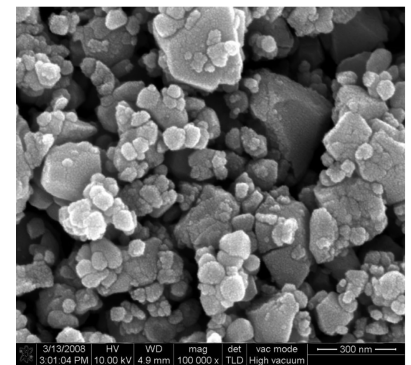

(c)

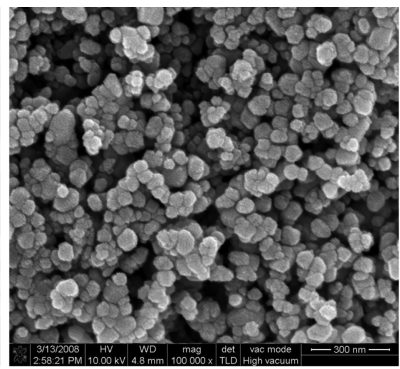

(b)

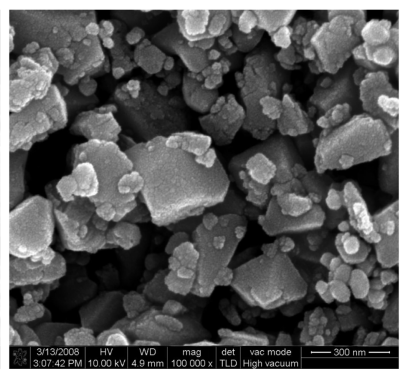

(d)
Fig. 5. SEM pictures of the various $\mathrm{NiO}$ precursors of: (a) $1 \mathrm{~N} 9 \mathrm{C}$, (b) $2 \mathrm{~N} 8 \mathrm{C}$, (c) $3 \mathrm{~N} 7 \mathrm{C}$, and (d) $4 \mathrm{~N} 6 \mathrm{C}$ heated to $750^{\circ} \mathrm{C}$ at a heating rate of $10^{\circ} \mathrm{C} / \mathrm{min}$ and held at that temperature for $2 \mathrm{~h}$.

of $5^{\circ} \mathrm{C} / \mathrm{min}$ and then at $1^{\circ} \mathrm{C} / \mathrm{min}$ to $450^{\circ} \mathrm{C}$ and held at that temperature for $2 \mathrm{~h}$. Their SEM pictures in Fig. 6 show that $1 \mathrm{~N} 9 \mathrm{C}$ and $2 \mathrm{~N} 8 \mathrm{C}$ are homogeneous and $\sim 20 \mathrm{~nm}$, but $3 \mathrm{~N} 7 \mathrm{C}$ consists of mainly $\sim 50 \mathrm{~nm}$ and a few $\sim 150 \mathrm{~nm}$ cubes, $4 \mathrm{~N} 6 \mathrm{C}$ shows 200 300 nm cubic crystals with some $\sim 20 \mathrm{~nm}$ particles. It is assumed that nanosize $\mathrm{NiO}$ particles grow into large crystals assisted by the $\mathrm{Ni}$ nitrate somehow. It is interesting that $4 \mathrm{~N} 6 \mathrm{C}$ shows more cubic particles for the calcined mixture at $450^{\circ} \mathrm{C}$ than that at $750^{\circ} \mathrm{C}$ but the cube sizes are almost same. It is believed that the cubic particles

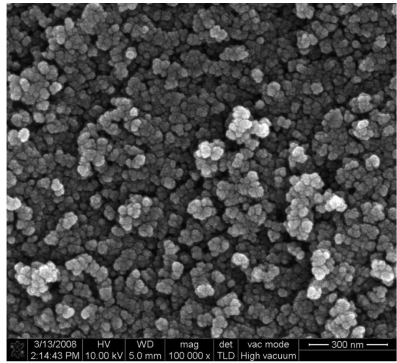

(a)

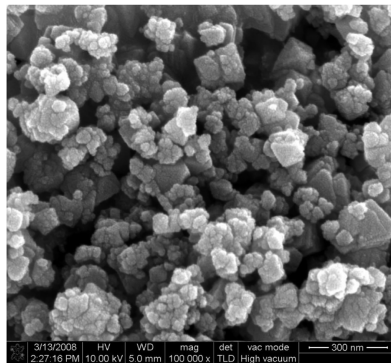

(c)

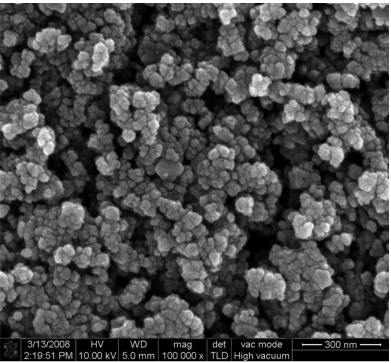

(b)

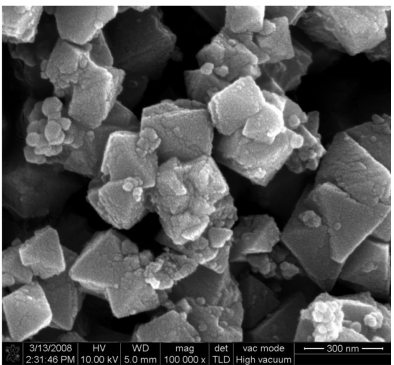

(d)
Fig. 6. SEM pictures of the various $\mathrm{NiO}$ precursors of: (a) $1 \mathrm{~N} 9 \mathrm{C}$, (b) $2 \mathrm{~N} 8 \mathrm{C}$, (c) $3 \mathrm{~N} 7 \mathrm{C}$, and (d) $4 \mathrm{~N} 6 \mathrm{C}$ heated to $450^{\circ} \mathrm{C}$ at various heating rates and held at that temperature for $2 \mathrm{~h}$.

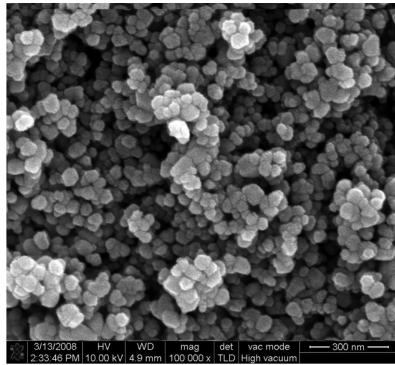

(a)

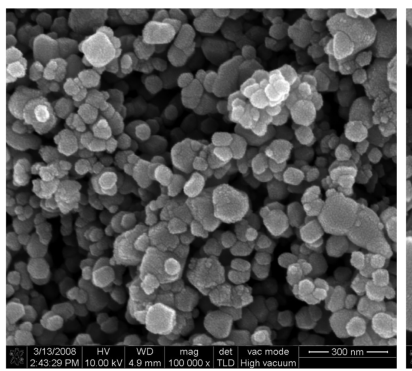

(c)

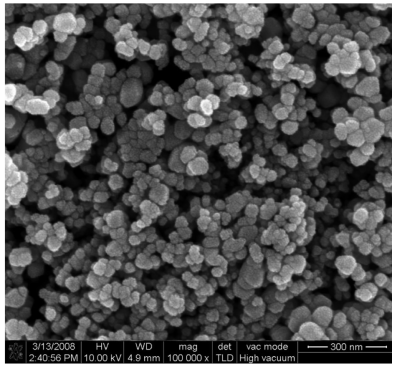

(b)

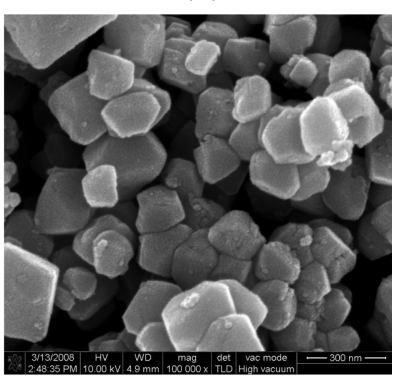

(d)
Fig. 7. SEM pictures of the various $\mathrm{NiO}$ precursors as heated in Fig. 6 and then further heated to $750^{\circ} \mathrm{C}$ at a heating rate of $2^{\circ} \mathrm{C} / \mathrm{min}$ and held at that temperature for $2 \mathrm{~h}$.

are grown at $450^{\circ} \mathrm{C}$ and are hardly influenced by higher calcination temperature. In the hope of obtaining uniform particles, the mixtures were held at $450^{\circ} \mathrm{C}$ for $2 \mathrm{~h}$ and then heated to $750^{\circ} \mathrm{C}$ at a heating rate of $2^{\circ} \mathrm{C} / \mathrm{min}$ and held at the temperature for $2 \mathrm{~h}$. The SEM pictures shown in Fig. 7 are well-grown crystals and more uniform for all the combina- 
tions. The $1 \mathrm{~N} 9 \mathrm{C}$ and $2 \mathrm{~N} 8 \mathrm{C}$ provide pseudo spherical particles with sizes of $50 \sim 70 \mathrm{~nm}$ and $30 \sim 60 \mathrm{~nm}$, respectively, which are not greatly influenced by either heating rate or by calcination temperature. However, 3N7C shows particles of $\sim 80 \mathrm{~nm}$ with a few $\sim 150 \mathrm{~nm}$ particles and the $4 \mathrm{~N} 6 \mathrm{C}$ show well grown cubic particles of $\sim 150 \mathrm{~nm}$ with some larger cubes and some aggregates. The crystals had smoother surface than those calcined at $450^{\circ} \mathrm{C}$ but the size remained almost same. This proves that the growth is limited by their combination, and the slow heating contributes to suppress the fast coalescense of small particles to result in more uniform growth.

The above observations reveal that a proper combination like $1 \mathrm{~N} 9 \mathrm{C}$ and $2 \mathrm{~N} 8 \mathrm{C}$ can produce uniform nanosize $\mathrm{NiO}$ particles. This simple approach can be applied to the preparation of other metal oxides.

\section{Conclusions}

Nano size $\mathrm{NiO}$ powder was prepared by simply mixing acidic nickel nitrate with basic nickel carbonate and followed by calcination. The mole ratio of the acid to the base governs the morphology and size distribution of the formed $\mathrm{NiO}$ powder. The proper mole ratio, $2 \mathrm{~N} 8 \mathrm{C}$, provided pseudo spherical $\mathrm{NiO}$ powder in $30 \sim 60 \mathrm{~nm}$ by heat treatment at $750^{\circ} \mathrm{C}$ for $2 \mathrm{~h}$.

\section{Acknowledgment}

We are grateful for the financial support by the Korea Energy Management Corporation under grant 2008-NFC12-J-03-3-040.

\section{REFERENCES}

1. C. L. Camer and K. J. Klabunde, "The Catalytic Methanol Synthesis Over Nanoparticle Metal Oxide Catalysts," $J$. Mol. Catal. A. Chem., 194 227-36 (2003).

2. J. R. Sohn and J. S. Han, "Physicochemical and Catalytic Properties of $\mathrm{NiO}-\mathrm{TiO}_{2}$ Modified with $\mathrm{WO}_{3}$ for Ethylene Dimerization," Appl. Catal. A Gen., 298 168-276 (2006).

3. E. L. Miller and R. E. Rocheleau, "Electrochemical Behavior of Reactively Sputtered Iron-Doped Nickel Oxide," J. Electrochem. Soc., 144 [9] 3072-77 (1997).

4. M. Yoshio, Y. Todorov, K. Yamato, H. Noguchi, J. Itoh, M. Okada, and T. Mouri, "Preparation of $\mathrm{Li}_{\mathrm{y}} \mathrm{Mn}_{\mathrm{x}} \mathrm{Ni}_{1-\mathrm{x}} \mathrm{O}_{2}$ as a Cathode for Lithium-ion Batteries," J. Power Sources, 74 46-53 (1998).

5. V. Biju and M. A. Khadar, "Analysis of AC Electrical Properties of Nanocrystalline Nickel Oxide," Mater. Sci. Eng., A 304 814-17 (2001).

6. F. Tietz, F. J. Dias, D. Simwonis, and D. Stover, "Evaluation of Commercial Nickel Oxide Powders for Components in Solid Oxide Fuel Cells," J. Euro. Ceram. Soc., 20 1023-34 (2000).

7. X. Deng and Z. Chen, "Preparation of Nano-NiO by Ammonia Precipitation and Reaction in Solution and Competitive Balance," Mater. Lett., 58 276-80 (2004).
8. F. Porta, S. Recchia, C. Bianchi, F. Confalonieri, and G. Scari, "Synthesis and Full Characterisation of Nickel(II) Colloidal Particles and Their Transformation Into NiO," Colloids Surf (A): Physicochem. Eng. Aspects, 155 395-404 (1999).

9. X. Xin, Z. Lu, B. Zhou, X. Huang, R. Zhu, X. Sha, Y. Zhang, and W. Su, "Effect of Synthesis Conditions on the Performance of Weakly Agglomerated Nanocrystalline NiO," J. Alloys and Compd., 427 251-55 (2007).

10. L. Xiang, X. Y. Deng, and Y. Jin, "Experimental Study on Synthesis of NiO Nano-particles," Scripta Mater., 47 21924 (2002)

11. X. M. Liu, X. G. Zhang, and S. Y. Fu, "Preparation of Urchinlike NiO Nanostructures and Their Electrochemical Capacitive Behaviors," Mater. Res. Bull., 41 620-27 (2006).

12. C.-J. Li, X.-X. Huang, Y. Shi, and J.-K. Guo, "Preparation and Characteristics of Nanocrystalline $\mathrm{NiO}$ by Organic Solvent Method," Mater. Lett., 51 325-30 (2001).

13. B. Malecka, A. Malecki, E. Drozdz-Ciesla, L. Tortet, P. Llewellyn, and F. Rouquerol, "Some Aspects of Thermal Decomposition of $\mathrm{NiC}_{2} \mathrm{O}_{4} \cdot 2 \mathrm{H}_{2} \mathrm{O}$," Thermochim. Acta, 466 57-62 (2007).

14. Y. Wu, Y. He, T. Wu, T. Chen, W. Weng, and H. Wan, "Influence of Some Parameters on the Synthesus of Nanosized NiO Material by Modified Sol-gel Method," Mater. Lett., 61 3174-78 (2007).

15. Q. Li, L.-S. Wang, B.-Y. Hu, C. Yang, L. Zhou, and L. Zhang, "Preparation and Characterization of NiO Nanoparticles Through Calcination of Malate Gel," Mater. Lett., 61 1615-18 (2007).

16. Y. Wang, C. Ma, and X. Sun, "Preparation of Nanocrystalline Metal Oxide Powders with the Surfactant-mediated Method," Inorg. Chem. Commun., 5 751-55 (2002).

17. T. Sreethawong, S. Chavadej, S. Ngamsinlapasathian, and S. Yoshikawa, "A Modified Sol-gel Process-derived Highly Nanocrystalline Mesoporous $\mathrm{NiO}$ with Narrow Pore Size Distribution," Colloids Surf (A): Physicochem. Eng. Aspects, 296 222-29 (2007).

18. E. I. Eweka and D. H. Kerridge, "Molten Sodium Nitritesodium Nitrate-potassium Nitrate Eutectic: The Reactions and Spectra of Iron(III), Cobalt(II), Nickel(II) and Copper(II) compounds," Thermochim. Acta, 290 133-38 (1996).

19. Y. Wang, J. Zhu, X. Yang, L. Lu, and X. Wang, "Preparation of NiO Nanoparticles and Their Catalytic Activity in the Thermal Decomposition of Ammonium Perchlorate," Thermochim. Acta, 437 106-9 (2005).

20. C. Popescu, I. Ursu, M. Popescu, R. Alexandrescu, I. Morjan, I. N. Mihailescu, and V. Jianu, "Specific Features of Nickel Oxides Obtained by Thermal and Laser Induced Decomposition of Nickel Salts. A Comparative Study," Thermochim. Acta, 164 79-90 (1990).

21. W. Brockner, C. Ehrhardt, and M. Gjikaj, "Thermal Decomposition of Nickel Nitrate Hexahydrate, $\mathrm{Ni}\left(\mathrm{NO}_{3}\right)_{2}$ $\cdot 6 \mathrm{H}_{2} \mathrm{O}$, in Comparison to $\mathrm{Co}\left(\mathrm{NO}_{3}\right)_{2} \cdot 6 \mathrm{H}_{2} \mathrm{O}$ and $\mathrm{Ca}\left(\mathrm{NO}_{3}\right)_{2} \cdot 4 \mathrm{H}_{2} \mathrm{O}$," Thermochim. Acta, 456 64-68 (2007).

22. Y. Li, Z.-y. Luo, C. Yu, D. Luo, Z. Xu, and K. Cen, "The Impact of $\mathrm{NiO}$ on Microstructure and Electrical Property of Solid Oxide Fuel Cell Anode," J. Zhejiang Univ. SCI., 6B 1124-29 (2005) 